\title{
Limit-Feeding a High-Energy Diet to Meet Energy Requirements in the Dry Period Alters Plasma Metabolite Concentrations but Does Not Affect Intake or Milk Production in Early Lactation
}

\author{
L. A. Winkelman, ${ }^{* 1}$ T. H. Elsasser, $\dagger$ and C. K. Reynolds ${ }^{\star 2,3}$ \\ *Department of Animal Sciences, The Ohio State University, OARDC, Wooster 44691 \\ †USDA Agricultural Research Service, Beltsville, MD 20705
}

\section{ABSTRACT}

Limit-feeding dry cows a high-energy diet may enable adequate energy intake to be sustained as parturition approaches, thus reducing the extent of negative energy balance after parturition. Our objective was to evaluate the effect of dry period feeding strategy on plasma concentrations of hormones and metabolites that reflect energy status. Multiparous Holstein cows $(n=18)$ were dried off $45 \mathrm{~d}$ before expected parturition, paired by expected calving date, parity, and previous lactation milk yield, and randomly assigned to 1 of 2 dry-period diets formulated to meet nutrient requirements at ad libitum or limited intakes. All cows were fed the same diet for ad libitum intake after parturition. Prepartum dry matter intake (DMI) for limit-fed cows was $9.4 \mathrm{~kg} /$ d vs. $13.7 \mathrm{~kg} / \mathrm{d}$ for cows fed ad libitum. During the dry period, limit-fed cows consumed enough feed to meet calculated energy requirements, and ad libitum-fed cows were in positive calculated net energy for lactation $\left(\mathrm{NE}_{\mathrm{L}}\right)$ balance (0.02 vs. $6.37 \mathrm{Mcal} / \mathrm{d}$, respectively). After parturition, milk yield, milk protein concentration, DMI, body condition score, and body weight were not affected by the prepartum treatments. Cows limit fed during the dry period had a less-negative calculated energy balance during wk 1 postpartum. Milk fat concentration and yield were greater for the ad libitum treatment during wk 1 but were lower in wk 2 and 3 postpartum. Plasma insulin and glucose concentrations decreased after calving. Plasma insulin concentration was greater in ad libitum-fed cows on $d-2$ relative to calving, but did not differ by dietary treatment at other times. Plasma glucose concentrations were lower before

Received June 11, 2007.

Accepted November 25, 2007.

${ }^{1}$ Current address: Department of Animal Sciences, Cornell University, Ithaca, NY.

${ }^{2}$ Corresponding author: c.k.reynolds@reading.ac.uk

${ }^{3}$ Current address: Department of Agriculture, The University of Reading, PO Box 237, Earley Gate, Reading, Berkshire, RG6 6AR, UK. and after parturition for cows limit-fed during the dry period. Plasma nonesterified fatty acid concentrations peaked after parturition on $\mathrm{d} 1$ and 4 for the limitfed and ad libitum treatments, respectively, and were greater for limit-fed cows on $\mathrm{d}-18,-9,-5$, and -2 . Plasma tumor necrosis factor- $\alpha$ concentrations did not differ by treatment in either the pre- or postpartum period, but tended to decrease after parturition. Apart from a reduction in body energy loss in the first week after calving, limit feeding a higher $\mathrm{NE}_{\mathrm{L}}$ diet during the dry period had little effect on intake and milk production during the first month of lactation.

Key words: limit feeding, energy balance, dry period, transition

\section{INTRODUCTION}

Concurrent with the metabolic and endocrine changes cows undergo during the transition to lactation, DMI often decreases in the last few days before parturition (Bertics et al., 1992), exacerbating the characteristic negative energy balance (EB) of the earlylactation cow (Grummer, 1995). Decreases in DMI and EB before parturition predispose the cow to development of metabolic disorders, such as fatty liver and ketosis (Grummer, 1995; Goff and Horst, 1997). Minimizing the negative EB associated with calving has been a focus of transition cow research for over a decade, as evidenced by the number of reviews published on the subject (Bell, 1995; Grummer, 1995; Goff and Horst, 1997; Drackley, 1999; Ingvartsen and Andersen, 2000; NRC, 2001; Overton and Waldron, 2004).

Cows typically begin to decrease their DMI over the last $3 \mathrm{wk}$ of pregnancy with the greatest decreases occurring in the final week prepartum (Grummer, 1995; Hayirli et al., 2002). Limit feeding high-energy diets to meet energy requirements during the dry period might enable adequate energy consumption in the late-gestation cow approaching parturition. In 2 studies (Kunz et al., 1985; Holcomb et al., 2001), cows limit fed highenergy diets maintained constant energy balance before parturition, whereas cows fed ad libitum experienced 
a decline in energy balance before calving. These results show that an energy-dense, limit-fed diet during the dry period does not hinder postpartum milk yield or DMI. Of more practical importance, cows limit-fed during the dry period increased DMI more rapidly after parturition than cows fed ad libitum (Holcomb et al., 2001). Holtenius et al. (2003) reported that cows fed below energy requirements during the dry period had numerically greater intake after parturition, although postpartum DMI was not statistically different across feeding groups.

Tumor-necrosis factor- $\alpha$ (TNF- $\alpha$ ) is an acute phase protein produced in response to immune system challenges, which may include the metabolic disorders that occur in the periparturient period (Elsasser et al., 2006). Sordillo et al. (1995) examined TNF- $\alpha$ production in vitro from mononuclear cells isolated from periparturient cows and mid- to late-lactation cows. When the cells were stimulated with LPS, monocytes from periparturient cows produced more TNF- $\alpha$ compared with monocytes from mid- to late-lactation cows. Perkins et al. (2002) subjected cows to feed restriction at $80 \%$ of maintenance requirements and reported greater serum TNF- $\alpha$ concentrations after endotoxin challenge. Liver production of TNF- $\alpha$ mRNA (Loor et al., 2005) increases after parturition, but to our knowledge, plasma TNF$\alpha$ concentrations during the periparturient period have not been reported.

Limit-feeding a high-energy diet to meet nutrient requirements during gestation may prevent the large decrease in DMI that normally occurs before parturition, and thus maintain a more constant energy balance before parturition. We hypothesized that limit-feeding cows during the dry period would improve their metabolic status after calving, as evidenced by changes in the plasma parameters measured (e.g., reduced NEFA and increased insulin concentrations). Therefore, the goal of the present study was to evaluate the effects of dry period feeding strategy on plasma concentrations of TNF- $\alpha$ and other hormones and metabolites, as potential physiological responses associated with the production responses observed in other studies. Effects on components of the somatotropic axis are reported separately (Winkelman et al., 2008).

\section{MATERIALS AND METHODS}

\section{Cows, Diets, and Experimental Design}

All procedures were conducted following protocols approved by The Ohio State University Agricultural Animal Care and Use Committee. Eighteen multiparous Holstein cows paired by parity, expected parturition date, and previous lactation performance were dried off $45 \mathrm{~d}$ before expected parturition, weighed, and ran- domly assigned to 1 of 2 dietary treatments. Cows were housed in individual tie stalls and fed 1 of 2 diets (Tables 1 and 2) at either limited (L) or ad libitum (AL) DMI. Diets were formulated to meet nutrient requirements (NRC, 2001) based on a BW of $670 \mathrm{~kg}$ and a daily DMI of $8.5 \mathrm{~kg}$ for L and $12.0 \mathrm{~kg}$ for AL. The actual DM offered for each L cow was calculated on a BW basis at dry-off. Calcium chloride and magnesium sulfate were added to reduce the DCAD based on forage mineral analysis (Table 1). During the dry period cows were moved individually to box stalls for approximately $1 \mathrm{~h} / \mathrm{d}$ to provide exercise. Seven days before expected parturition date, cows were moved into individual box stalls for parturition. When AL cows were in box stalls they received a close-up diet (ALCU) until parturition (Tables 1 and 2 ), whereas L cows received the same diet throughout the entire dry period. After parturition, all cows were fed the same lactation diet ad libitum (Tables 1 and 2). Fresh cows were returned to tie stalls on d 3 postpartum unless health problems were observed. The cows remained in tie stalls until the study ended at $d 28$ postpartum, with exercise provided as the cows walked to and from the parlor for milking. Cows had free access to water at all times.

\section{Measurements}

Body condition scores and BW were measured weekly throughout the study. Evaluation of BCS was conducted by the same person using a 1 to 5 scale, with 1 being severely underconditioned and 5 being severely overconditioned (Wildman et al., 1982). Calf weights were recorded at birth.

Sampling and Analysis of Feed and Milk. Diets were fed once a day as a mixed ration. Total amount of feed offered and refused was measured daily. Diet components were sampled weekly and dried at $100^{\circ} \mathrm{C}$ overnight for determination of DM. Results from the DM determination were used to adjust the ration for changes in component moisture content. Weekly feed samples were composited monthly for analysis. Composite forage samples were lyophilized before analysis. All samples were ground using a Wiley mill (1-mm screen; Arthur H. Thomas, Philadelphia, PA) and analyzed as described by Weiss and Wyatt (2000) for concentrations of $\mathrm{DM}\left(100^{\circ} \mathrm{C}\right), \mathrm{NDF}$ (using sodium sulfite and heat-stable $\alpha$-amylase; Ankom ${ }^{200}$ Fiber Analyzer, Ankom Technology, Fairport, NY), ash $\left(600^{\circ} \mathrm{C}\right)$, CP (macro Kjeldahl $\mathrm{N} \times 6.25$ ), and starch. Diet concentrations of these components were calculated from feed component analyses (Table 2).

Cows were milked twice daily in the herd parlor except when in box stalls, where they were milked with a portable milking unit. Milk samples were obtained 
Table 1. Ingredient composition of diets (\% of DM) fed at limited (L) or ad libitum (AL) intakes during the dry period, a close-up diet (ALCU) fed to AL cows during the week before parturition, and a postpartum diet fed to all cows after parturition

\begin{tabular}{|c|c|c|c|c|}
\hline \multirow[b]{2}{*}{ Ingredient, \% of DM } & \multicolumn{3}{|c|}{ Prepartum $\operatorname{diet}^{1}$} & \multirow{2}{*}{$\frac{\text { Postpartum diet }}{\mathrm{L} \text { and } \mathrm{AL}}$} \\
\hline & $\mathrm{L}$ & $\mathrm{AL}$ & ALCU & \\
\hline Corn silage & 35.0 & 35.0 & 30.0 & 35.7 \\
\hline Alfalfa silage & 20.0 & - & 25.0 & 15.7 \\
\hline Grass silage & - & 30.0 & - & - \\
\hline Alfalfa hay & - & - & - & 3.7 \\
\hline Grass hay & - & 10.0 & 10.0 & - \\
\hline Ground corn & 10.7 & 9.4 & 8.3 & 14.1 \\
\hline Soybean meal, $44 \% \mathrm{CP}$ & 11.3 & 12.9 & 8.8 & 7.1 \\
\hline Treated soybean meal ${ }^{2}$ & - & - & - & 3.0 \\
\hline Soybean hulls & 19.7 & - & 15.3 & 6.8 \\
\hline Roasted soybeans & - & - & - & 10.0 \\
\hline Distillers dried grains & - & - & - & 1.0 \\
\hline Biotin, $220 \mathrm{mg} / \mathrm{kg}$ & 0.95 & 0.66 & 0.74 & 0.37 \\
\hline Animal/vegetable fat & 0.36 & 0.35 & 0.28 & 0.35 \\
\hline Calcium chloride & 0.31 & 0.38 & 0.24 & - \\
\hline Magnesium sulfate & 0.13 & 0.18 & 0.10 & - \\
\hline Sodium bicarbonate & - & - & - & 0.51 \\
\hline Vitamins and minerals ${ }^{3}$ & 1.61 & 1.18 & 1.32 & 1.72 \\
\hline
\end{tabular}

${ }^{1} \mathrm{~L}$ = high-energy diet limit-fed; $\mathrm{AL}=$ low-energy diet fed ad libitum; ALCU = transition diet fed to $\mathrm{AL}$ cows approximately $7 \mathrm{~d}$ before expected parturition date.

${ }^{2}$ SurePro, Land O'Lakes, Shoreview, MN.

${ }^{3}$ Varying amounts of limestone, dicalcium phosphate, trace mineralized salt, zinc sulfate, zinc-methionine complex (Zinpro 100, Zinpro Corp., Eden Prairie, MN), copper sulfate, selenium, magnesium oxide, and vitamins A, D, and E were added to each diet to meet NRC (2001) recommendations for minerals and vitamins.

weekly for the 28-d period after parturition by sampling 2 consecutive milkings. On average, these samples were obtained at $3.3 \pm 1.8,10.3 \pm 1.8,17.6 \pm 2.8$, and $25.5 \pm$ 3.4 DIM. Samples were treated with preservative (bronopol) and stored at $4^{\circ} \mathrm{C}$ until analyzed for fat, true milk protein, lactose, and nonfat solids by infrared analysis (DHI Cooperative, Powell, OH).

Net energy intake $\left(\mathbf{N E}_{\mathbf{I}}\right)$ was determined by multiplying daily DMI by the calculated energy value of the $\operatorname{diet}(\mathrm{NRC}, 2001)$. Maintenance requirements $\left(\mathbf{N E}_{\mathbf{M}}\right)$ were calculated using the equation $\mathrm{NE}_{\mathrm{M}}=\mathrm{BW}^{0.75} \times$ 0.08 (NRC, 2001). Pregnancy requirements $\left(\mathbf{N E}_{\mathbf{P}}\right)$ were calculated using the equation $\mathrm{NE}_{\mathrm{P}}=[(0.00318 \times$ days pregnant - 0.0352) $\times($ calf birth weight/45)] / 0.218 (NRC, 2001). Actual calf birth weight information was used for each cow. Day of pregnancy was calculated retrospectively, using actual parturition and breeding dates. Estimated tissue EB during the prepartum period was computed on a daily basis using the equation $\mathrm{EB}=\mathrm{NE}_{\mathrm{I}}-\left(\mathrm{NE}_{\mathrm{M}}+\mathrm{NE}_{\mathrm{P}}\right)$. Estimated lactation requirements $\left(\mathrm{NE}_{\mathrm{L}}\right)$ were calculated on a daily basis according to the equation from $\mathrm{NRC}(2001)$, where $\mathrm{NE}_{\mathrm{L}}=$ milk yield $\times[(0.0929 \times$ fat percent $)+(0.0563 \times$ true protein percent $)+(0.0395 \times$ lactose percent $)$, using weekly com-

Table 2. Composition of diets fed at limited (L) or ad libitum (AL) intakes during the dry period, a closeup diet fed to AL cows during the dry period (ALCU) during the week before parturition, and a postpartum diet fed to all cows after parturition

\begin{tabular}{lcccc}
\hline & \multicolumn{3}{c}{ Prepartum diet $^{1}$} & \\
\cline { 2 - 4 } Chemical composition $^{3}$ & $\mathrm{~L}$ & $\mathrm{AL}$ & ALCU & L and AL \\
\hline $\mathrm{NE}_{\mathrm{L}}, \mathrm{Mcal} / \mathrm{kg}$ & 1.69 & 1.57 & 1.61 & 1.75 \\
$\mathrm{DM}, \%$ & 53.6 & 48.8 & 55.5 & 54.3 \\
$\mathrm{CP}, \%$ & 14.0 & 12.7 & 15.7 & 16.8 \\
$\mathrm{NDF}, \%$ & 41.2 & 42.4 & 42.8 & 33.4 \\
Starch, \% & 19.6 & 20.5 & 16.3 & 22.6 \\
Ash, \% & 7.3 & 7.7 & 8.0 & 7.3 \\
\hline
\end{tabular}

${ }^{1} \mathrm{~L}=$ high-energy diet limit-fed; $\mathrm{AL}=$ low-energy diet fed ad libitum; $\mathrm{ALCU}=$ transition diet fed to $\mathrm{AL}$ cows approximately $7 \mathrm{~d}$ before expected parturition date.

${ }^{2}$ All cows received the same diet after parturition.

${ }^{3} \mathrm{DM}$ basis except DM content expressed on an as-fed basis. 


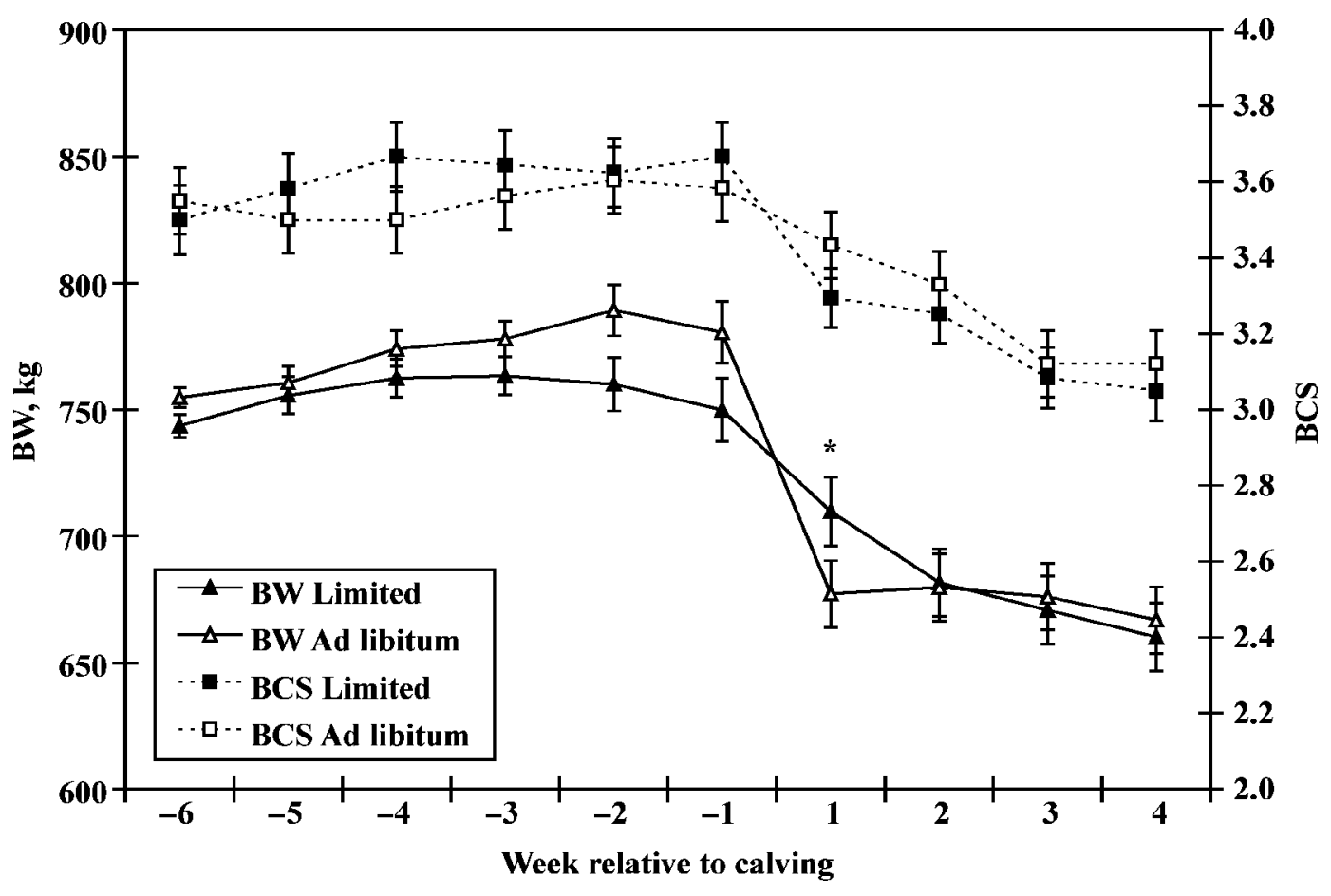

Figure 1. Weekly BW and BCS for cows fed limited or ad libitum diets during the dry period. Data presented are least squares means with their standard errors. Differences between treatments on specific days $(P<0.10)$ are denoted by the asterisk $(*)$. For prepartum BW: treatment, $P<0.095$; week, $P<0.001$; treatment $\times$ week interaction, $P<0.507$. For prepartum BCS: treatment, $P<0.558$; week, $P<0.701$; treatment $\times$ week interaction, $P<0.146$. For postpartum BW: treatment, $P<0.769$; week, $P<0.004$; treatment $\times$ week interaction, $P<$ 0.017. For postpartum BCS: treatment, $P<0.401$; week, $P<0.001$; treatment $\times$ week interaction, $P<0.865$.

position data. Estimated EB during the postpartum period was calculated on a daily basis using the equation $\mathrm{EB}=\mathrm{NE}_{\mathrm{I}}-\left(\mathrm{NE}_{\mathrm{M}}+\mathrm{NE}_{\mathrm{L}}\right)$.

Collection of Blood Samples. Blood was collected weekly via coccygeal venipuncture beginning at dryoff. Samples were collected between 0800 and $1000 \mathrm{~h}$ in sterile $20-\mathrm{mL}$ heparin-rinsed $(1,000 \mathrm{U} / \mathrm{mL})$ syringes and then transferred to tubes treated with benzamadine-EDTA (Relling and Reynolds, 2007). Blood samples were transported on ice to the laboratory and immediately centrifuged at $3,000 \times g$ for $20 \mathrm{~min}$ at $4^{\circ} \mathrm{C}$. Aliquots of plasma were frozen at $-86^{\circ} \mathrm{C}$ until assayed.

Immediately before and after parturition, blood samples were collected more frequently to account for expected variations in plasma concentrations of insulin and other hormones (Winkelman et al., 2008) and more accurately describe expected changes in plasma concentrations during transition. These more-frequent blood samples were obtained using a jugular vein catheter implanted on $d-6$ relative to expected parturition as described by Relling and Reynolds (2007). During jugular vein sampling, $10-\mathrm{mL}$ blood samples were collected 6 times each day beginning at $0730 \mathrm{~h}$ and then every 90 min thereafter. The frequent blood sampling protocol was carried out on Mondays and Thursdays before calv- ing (which were normalized to $d-5$ and -2 ), and on $d$ 1,4 , and 7 postpartum (with day of parturition representing $d$ 0). After each sampling time point during the repeated blood sampling periods, equal volumes of plasma were added to a single tube to produce a pooled sample for analysis. On d 14, 21, and 28, one $20-\mathrm{mL}$ blood sample per day was collected via coccygeal venipuncture.

Analysis of Plasma Metabolites and Hormones. Plasma was analyzed for glucose, insulin, NEFA, and TNF- $\alpha$ concentrations. All samples from one cow were included in the same assay run to eliminate interassay variation for concentrations measured within individual cows. Glucose was measured using a commercial enzymatic assay (Trinder No. 1070; Stanbio Laboratory, Boerne, TX) adapted for use with a plate reader (Relling and Reynolds, 2007). Intra- and interassay CV were 4.3 and $8.0 \%$, respectively. An enzymatic method was also used for determination of NEFA (NEFA C kit, Wako Pure Chemical Industries Ltd., Richmond, VA) as described by Johnson and Peters (1993). Intra- and interassay CV were 3.5 and $5.2 \%$, respectively. Insulin was measured using the equilibrium RIA described by Benson and Reynolds (2001). Intra- and interassay CV 

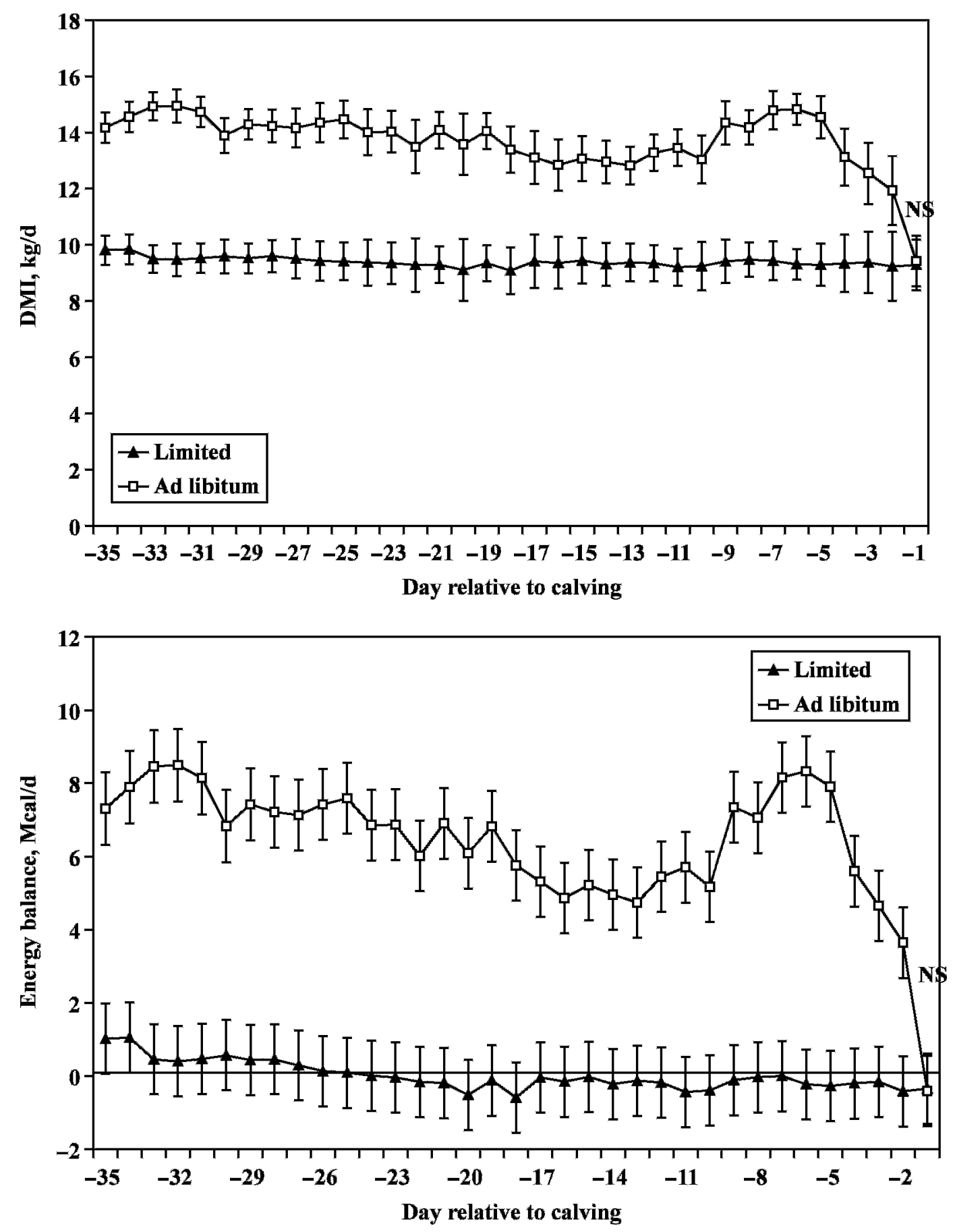

Figure 2. Daily prepartum DMI and energy $\left(\mathrm{NE}_{\mathrm{L}}\right)$ balance for cows fed either a limited or ad libitum diet during the dry period. Data are least squares means and their standard errors. Ad libitum cows had greater DMI and $\mathrm{NE}_{\mathrm{L}}$ balance during the entire prepartum period except on $\mathrm{d}-1$, denoted by NS. For prepartum DMI: treatment, $P<0.001$; day, $P<0.001$; treatment $\times$ day interaction, $P<0.001$. For prepartum energy balance: treatment, $P<0.001$; day, $P<0.001$; treatment $\times$ day interaction, $P<0.001$.

were 9.6 and $5.0 \%$, respectively. Tumor necrosis factor$\alpha$ was measured by double-antibody RIA, as described by Kenison et al. (1990), using one assay with an intraassay CV of $9.0 \%$.

\section{Statistical Analysis}

For statistical analyses data from all 18 cows were included for measurements obtained before calving. 


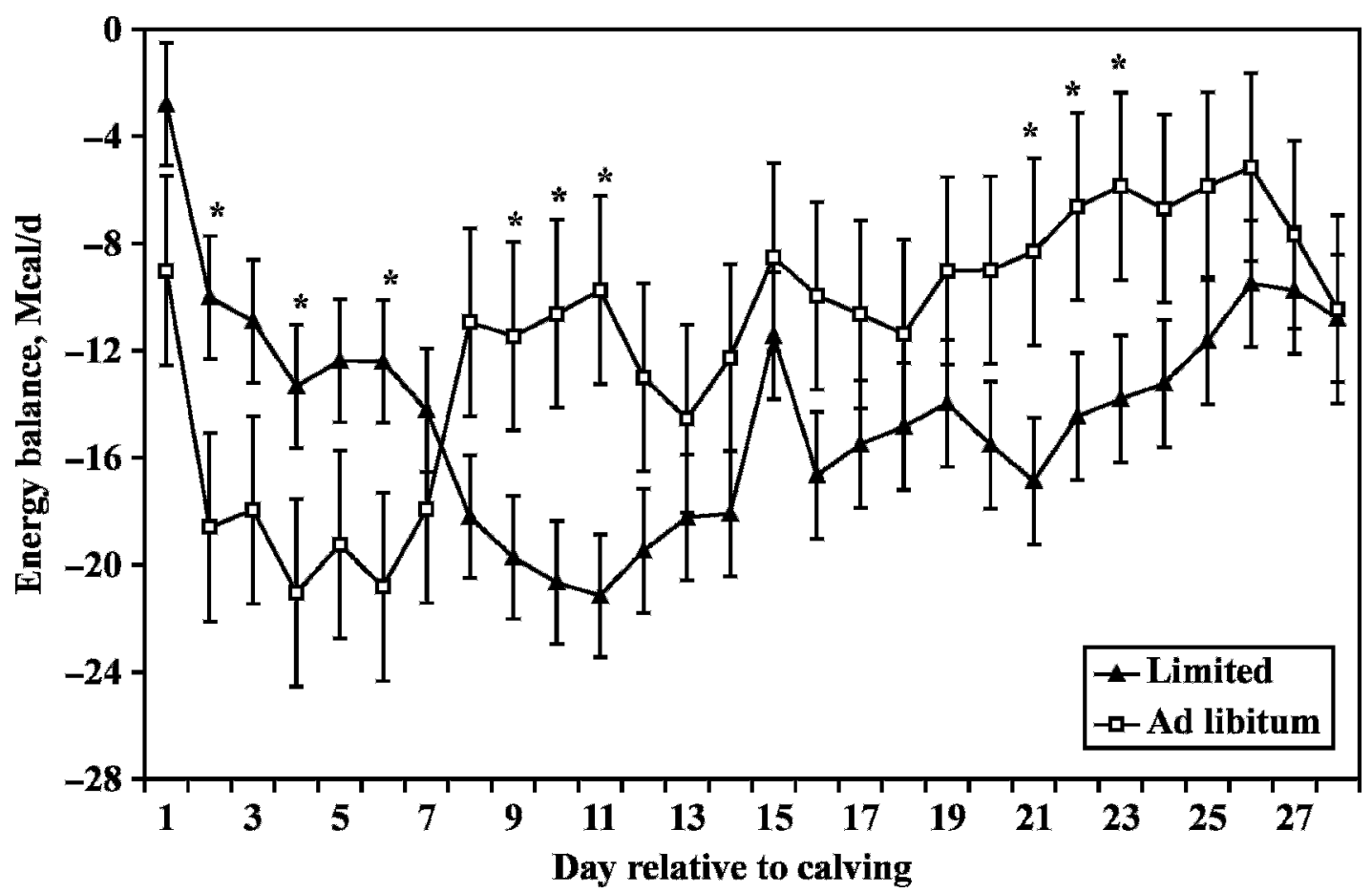

Figure 3. Daily postpartum energy $\left(\mathrm{NE}_{\mathrm{L}}\right)$ balance for cows fed either a limited or ad libitum diet during the dry period. Data are least squares means and their standard errors. Treatment, $P<0.228$; day, $P<0.001$; treatment $\times$ day interaction, $P<0.079$.

One AL cow was removed from the experiment at calving because it contracted salmonellosis immediately before parturition. Two AL cows tested positive for Staphylococcus aureus mastitis after calving and subsequently were diagnosed with a displaced abomasum on d 2 and 11 postpartum, after which they were culled from the herd. For postpartum production data, the number of cows whose data were included in the statistical analysis was 9 for $\mathrm{L}$ and 6 for AL, for a total of 15 cows for which DMI and milk yield data were obtained every day in the 4 -wk postpartum period.

Data were analyzed as repeated measures using the Mixed procedure of SAS (SAS Institute, 1999). For each analyzed variable, 5 covariance structures were compared: compound symmetric, heterogeneous compound symmetric, autoregressive order one, heterogeneous autoregressive order one, and unstructured. The covariance structure that yielded the smallest Bayesian information criterion was used for the results presented.

Pre- and postpartum data for plasma hormones and metabolites were combined for analysis to evaluate differences before and after calving. The model for the blood analyses included the main effects of treatment, period, day within period, and parity. The 2- and 3-way interactions of the main effects were also tested and the Slice option in the Mixed procedure was used to test for effects of diet at specific time points (SAS Institute, 1999). To simplify the analysis of DMI, EB, BW, and BCS, the pre- and postpartum data were analyzed separately, so that the model did not include the fixed effect of period or any of the interactions with period.

For all statistical analyses, initial measurements at dry-off were used for covariate adjustments. The effect of parity was simplified to second lactation and greater than second lactation. Three pairs of cows were included the "greater than second lactation" parity, with 2 pairs being in third lactation and 1 pair in fourth lactation. The random effect of pair by treatment represented the cow as a random effect. To protect against type II error, differences were considered to be significant at $P \leq 0.10$, tendency at $0.10<P \leq 0.20$, and lack of significance for $P>0.20$.

\section{RESULTS}

\section{$B W$ and $B C S$}

During the dry period, L cows weighed less $(P=0.095)$ than AL cows (756 vs. $773 \mathrm{~kg}$ for L vs. AL, respectively). Treatment did not affect calf birth weight. There was no effect of diet on pre- and postpartum BCS or postpartum BW. Time significantly affected both pre- and postpartum BW ( $P=0.01$ for pre- and postpartum, respectively; 


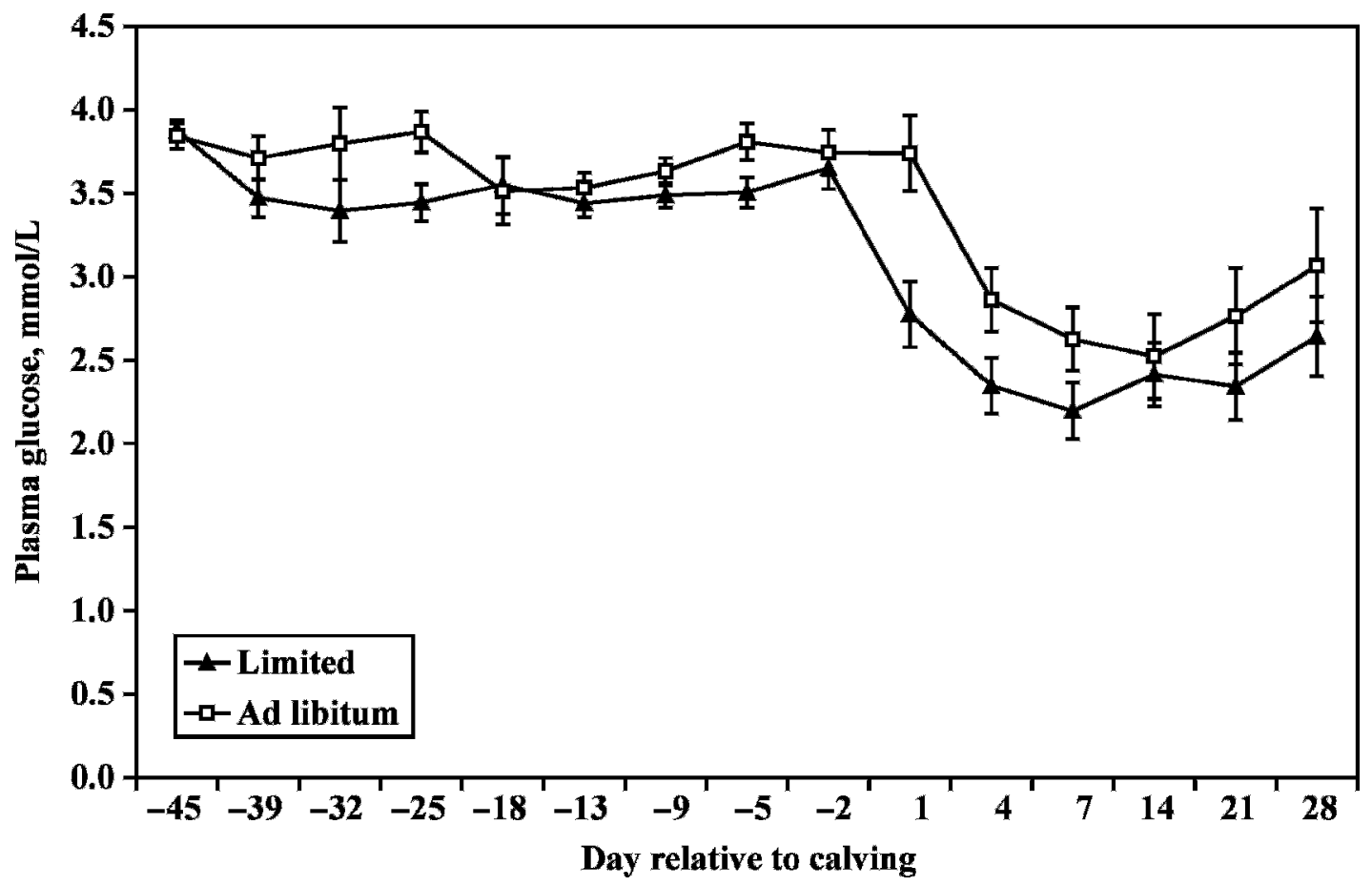

Figure 4. Plasma glucose concentrations in cows fed either a limited or ad libitum diet during the dry period. Data are least squares means and their standard errors. Period, $P<0.001$; treatment, $P=0.012$; day within period, $P<0.001$; treatment $\times$ day within period interaction, $P<0.155$.

Figure 1). An interaction $(P=0.02)$ between treatment and time was observed for postpartum BW, with L cows weighing more during wk 1 postpartum than $\mathrm{AL}(710$ vs. $677 \mathrm{~kg}$, respectively). Body condition decreased over time for all cows after parturition, regardless of treatment.

\section{Intake, EB, and Milk Production}

Dry matter intake and EB before parturition were greater for AL cows (Figure 2), as dictated by the experimental design. Mean DMI for L and AL cows were 9.4 and $13.7 \mathrm{~kg} / \mathrm{d}$, respectively. There was a treatment by day interaction for both prepartum DMI and EB, and both DMI and EB were greater for AL cows during most of the prepartum period. However, DMI of AL cows decreased during the $6 \mathrm{~d}$ before parturition such that DMI was not different from $L$ cows on $d-1$ (9.3 vs. 9.4 $\mathrm{kg} / \mathrm{d}$ for AL vs. L). Also, EB did not differ between the $\mathrm{AL}$ and $\mathrm{L}$ cows on the day before parturition ( $-0.40 \mathrm{vs}$. $-0.34 \mathrm{Mcal})$.

Postpartum DMI was similar for cows receiving $\mathrm{L}$ and AL treatments before calving (Table 3), and DMI increased as lactation progressed. Postpartum EB (Figure 3) was unaffected by prepartum treatment and varied over time. However, an interaction $(P=0.08)$ was detected between treatment and day for postpartum
EB. Cows fed the L diet during the dry period had greater EB on d 2, 4, and 6 but had lower EB on d 9, 10, 11, 21, 22, and 23 (Figure 3).

Milk yield did not differ between treatments (Table 3). Similarly, milk fat, protein, and lactose yield and concentration were unaffected by prepartum diet (Table $3)$. There was an interaction between treatment and time for milk fat yield $(P=0.002)$ and concentration $(P=0.001)$. During the first week after parturition, $\mathrm{AL}$ cows had greater milk fat percentage (6.63 vs. $4.39 \%)$ and fat yield (1.90 vs. $1.22 \mathrm{~kg} / \mathrm{d})$ compared with L cows. During wk 2 and 3, L cows had greater milk fat percentage (5.82 vs. $6.68 \%$ for wk 2 and 4.85 vs. $5.71 \%$ for wk 3 ) and fat yield (2.13 vs. $2.70 \mathrm{~kg} / \mathrm{d}$ for wk 2 and 2.01 vs. $2.61 \mathrm{~kg} / \mathrm{d}$ for wk 3 ).

\section{Hormone and Metabolite Concentrations}

Plasma glucose concentration decreased after parturition for all cows (3.62 vs. $2.69 \mathrm{mmol} / \mathrm{L}$, pre- vs. postpartum, respectively). Over the entire trial (pre- and postpartum combined), L cows had lower plasma glucose concentration compared with AL cows. Postpartum glucose concentration was lowest on $\mathrm{d} 7$ and $\mathrm{d} 14$ for $\mathrm{L}$ and AL cows, respectively (Figure 4)

Prepartum NEFA concentrations were not different between treatments. Plasma NEFA concentrations var- 
Table 3. Effects of feeding limited (L) or ad libitum (AL) diets during the dry period on DMI and production of dairy cows during the first 4 wk of lactation

\begin{tabular}{|c|c|c|c|c|c|c|}
\hline \multirow[b]{2}{*}{ Response variable } & \multicolumn{3}{|c|}{ Prepartum diet } & \multicolumn{3}{|c|}{$P<$} \\
\hline & $\mathrm{L}$ & $\mathrm{AL}$ & SEM & Treatment (Trt) & Time $^{1}$ & Trt $\times$ time \\
\hline DMI, kg/d & 19.0 & 19.8 & 0.46 & 0.3617 & $<0.0001$ & 0.5336 \\
\hline Milk yield, ${ }^{2} \mathrm{~kg} / \mathrm{d}$ & 41.9 & 41.1 & 1.31 & 0.750 & 0.001 & 0.636 \\
\hline Fat, $\%$ & 5.47 & 5.39 & 0.269 & 0.827 & 0.002 & 0.0001 \\
\hline Fat, kg/d & 2.25 & 2.02 & 0.154 & 0.365 & 0.001 & 0.002 \\
\hline Protein, ${ }^{3} \%$ & 3.31 & 3.20 & 0.079 & 0.421 & 0.001 & 0.419 \\
\hline Protein, kg/d & 1.25 & 1.19 & 0.061 & 0.579 & 0.003 & 0.771 \\
\hline Lactose, $\%$ & 4.48 & 4.61 & 0.066 & 0.236 & 0.001 & 0.695 \\
\hline Lactose, $\mathrm{kg} / \mathrm{d}$ & 1.81 & 1.78 & 0.087 & 0.792 & 0.001 & 0.584 \\
\hline
\end{tabular}

${ }^{1}$ Time for DMI and milk yield is in reference to days. For milk components, time is in reference to weeks.

${ }^{2}$ Signficant effect of parity $(P=0.032)$, with third or greater lactation cows having greater milk yield than second lactation cows, 44.2 vs. $38.0 \mathrm{~kg} / \mathrm{d}$, respectively.

${ }^{3}$ True protein.

ied over day of sampling, with concentrations increasing at parturition and then decreasing as lactation progressed (Figure 5). There was an interaction between treatment and day within period; L cows had greater NEFA concentrations on $\mathrm{d}-18,-9,-5$, and -2 relative to calving, and the increase in plasma NEFA concentration at calving for L cows preceded parturition by $2 \mathrm{~d}$.

Plasma insulin decreased as parturition approached, reaching the lowest concentration for both treatments on d 4 (Figure 6). There was no overall effect of treatment on plasma insulin concentrations, but there was a treatment by day within period interaction $(P<0.05)$. In the week before parturition, AL cows had greater plasma insulin concentrations on $\mathrm{d}-2$ compared with L cows.

Concentrations of plasma TNF- $\alpha$ did not differ by treatment but varied by day within period $(P=0.025)$ and tended $(P=0.11)$ to be lower after parturition for all

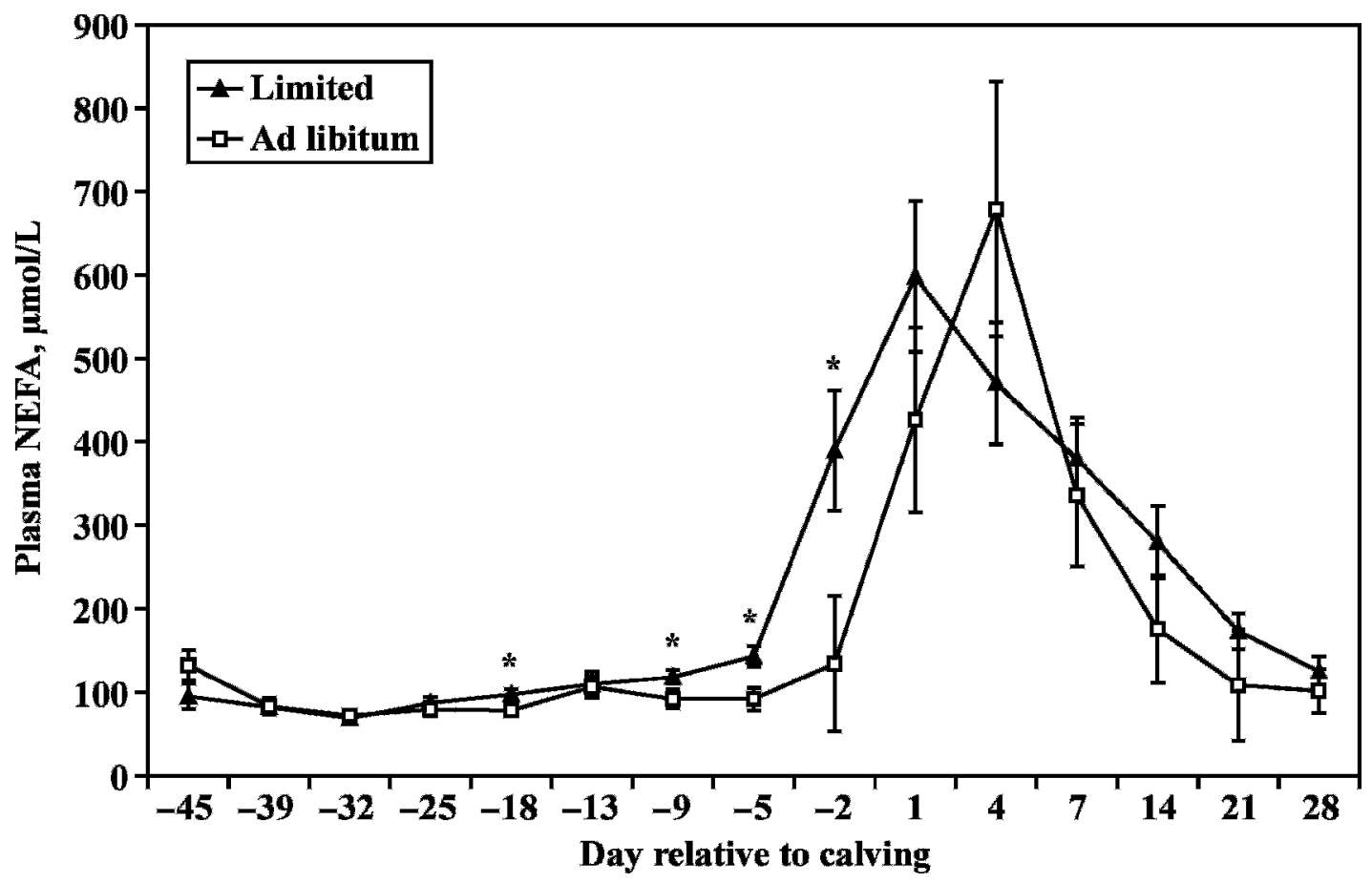

Figure 5. Plasma NEFA concentrations in cows fed either a limited or ad libitum diet during the dry period. Data are least squares means and their standard errors. Differences between treatments on specific days $(P<0.10)$ are denoted by the asterisk $(*)$. Period, $P<$ 0.256 ; treatment, $P=0.256$; day within period, $P<0.001$; treatment $\times$ day within period interaction, $P<0.078$. 


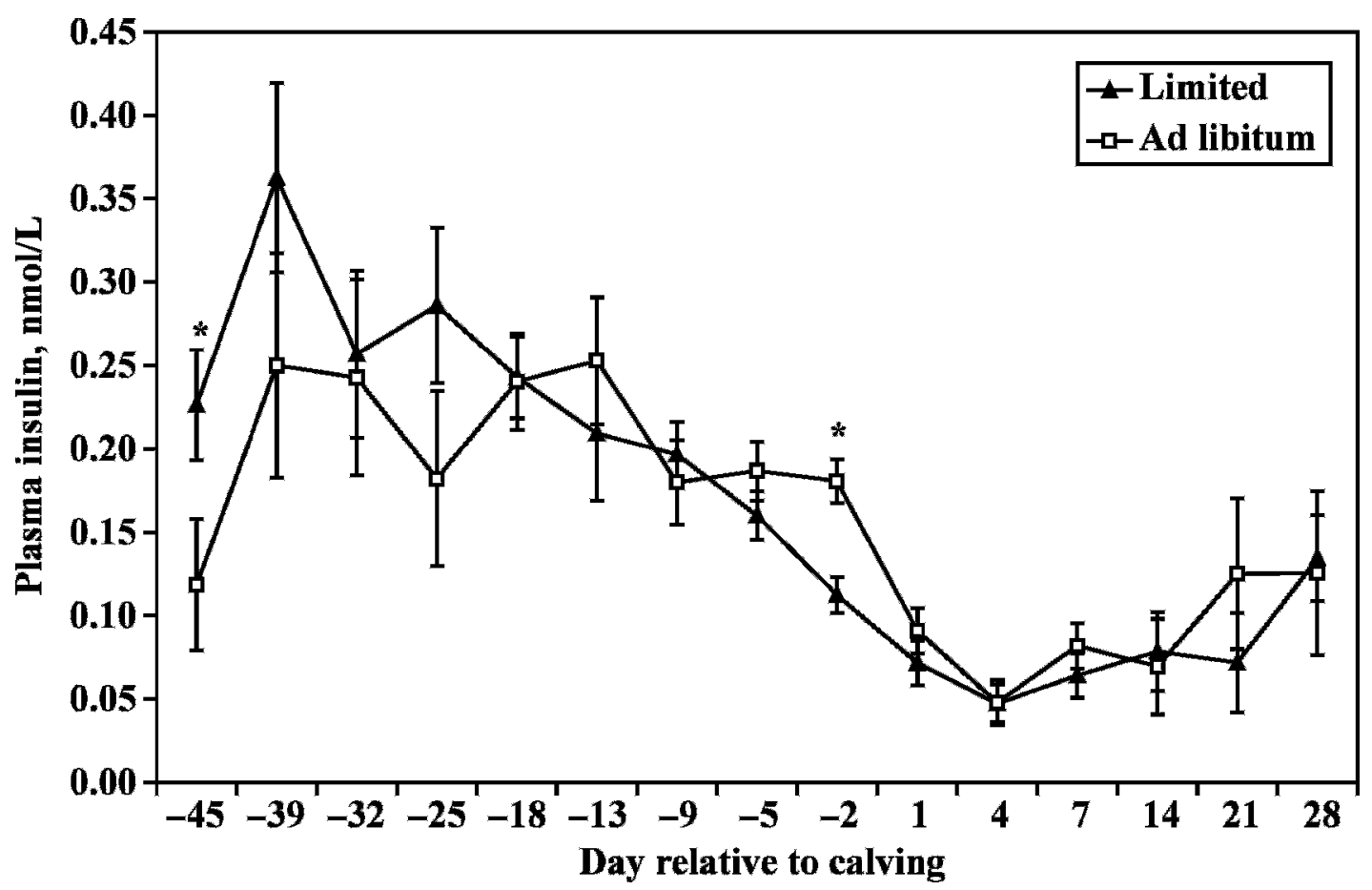

Figure 6. Plasma insulin concentrations in cows fed either a limited or ad libitum diet during the dry period. Data are least squares means and their standard errors. Differences between treatments on specific days $(P<0.10)$ are denoted by the asterisk $(*)$. Period, $P<$ 0.001; treatment, $P=0.753$; day within period, $P<0.001$; treatment $\times$ day within period interaction, $P<0.050$.

cows, regardless of treatment. There was an interaction between treatment and day within period $(P=0.02$; Figure 7), with L cows having greater plasma TNF- $\alpha$ concentrations on $\mathrm{d}-39$ and -5 and lower concentrations on $d-9$ and 14 .

\section{DISCUSSION}

\section{$B W$ and $B C S$}

Based on calculated energy requirements and BCS during the dry period, the L cows consumed enough energy to maintain body condition, but the L cows weighed approximately $17 \mathrm{~kg}$ less than AL cows. Some of this difference was likely due to reduced gut fill from the limited feed allowance. Most postpartum dairy cows lose BCS after parturition regardless of prepartum treatment, as observed in the present study and reported elsewhere (Keady et al., 2001; Contreras et al., 2004; Bernabucci et al., 2005). Moderate loss of BW over the first month postpartum is typical of high-yielding dairy cows (Doepel et al., 2002; Roche et al., 2005); in the present study, all cows lost BW and BCS after parturition (Figure 1). Greater BW for L cows immediately after calving also may have been due in part to a greater gain in gut fill after calving

\section{$D M I$ and EB}

Prepartum DMI and estimated EB were greater for AL cows, as dictated by experimental design. Holcomb et al. (2001) reported that cows that were limit-fed during the prepartum period had slightly increased DMI and milk yield in the first $40 \mathrm{~d}$ after calving when compared with ad libitum-fed controls. Similarly, Roche et al. (2005) showed that cows fed at or below energy requirements during the dry period tended to have greater DMI during wk 3 to 5 after parturition. However, there were no differences in postpartum DMI observed in the present study (Figure 3), which agrees with other studies reporting no effect of prepartum feed allowance or concentrate inclusion on postpartum DMI (Agenäs et al., 2003; McNamara et al., 2003).

The decrease in DMI in AL cows before calving was substantial, and on the day before parturition, DMI was $37 \%$ lower than the DMI on $d-7$. When looking at EB, which accounts for each cow's BW and calf birth weight, the drop in EB from $d-7$ to $d-1$ in AL cows was from 8.2 to $-0.4 \mathrm{Mcal} / \mathrm{d}$. However, as observed previously (Grummer, 1995), not all AL cows experienced this decline in DMI and EB as parturition approached. Therefore, some of the AL cows had much 


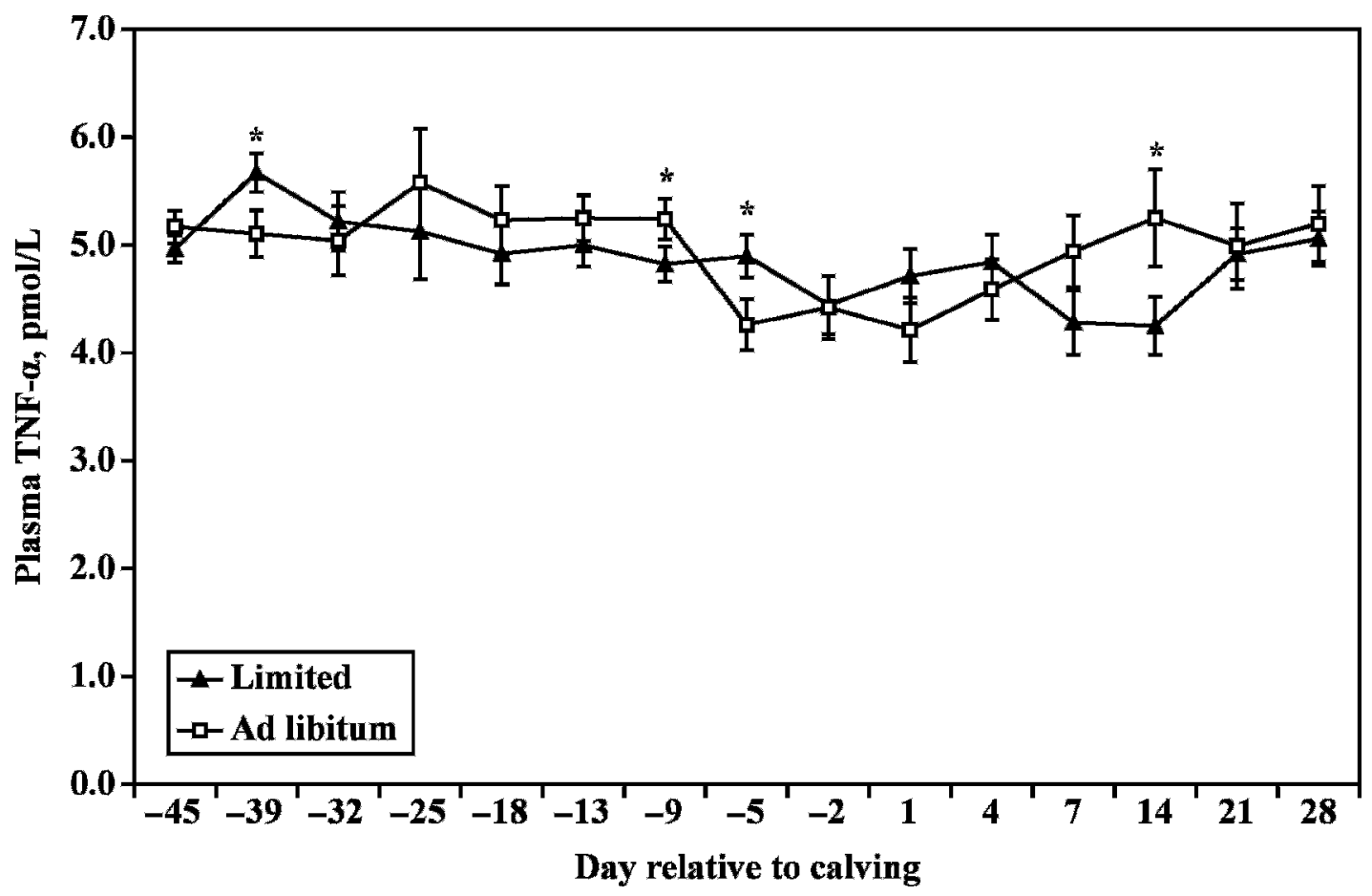

Figure 7. Plasma tumor necrosis factor- $\alpha$ concentrations in cows fed either a limited or ad libitum diet during the dry period. All cows received the same diet after parturition. Data are least squares means and their standard errors. Differences on specific days $(P<0.10)$ are denoted by the asterisk (*). Period, $P<0.111$; treatment, $P=0.513$; day within period, $P<0.025$; treatment $\times$ day within period interaction, $P<0.020$.

greater declines in DMI and EB than the average. In contrast to AL cows, cows fed the $\mathrm{L}$ diet did not reduce their DMI during the last 2 wk before parturition, and did not experience a decrease in net EB before calving.

The magnitude of the decrease in EB and intake of dairy cows at parturition has received attention in the recent literature (Holcomb et al., 2001; Rastani et al., 2005). Roche et al. (2005) suggests that beyond the first week after parturition, prepartum nutrient and DMI do not affect EB. In the present study, cows in both treatment groups experienced the characteristic negative EB balance of early lactation, but during the first week after parturition, L cows had greater EB compared with AL cows. Later in the postpartum period, AL cows had greater estimated EB on d 9, 10, 11, 21, 22, and 23. These differences in EB were due to differences in milk energy output, attributable to differences in milk fat yield discussed previously.

\section{Milk Production}

Milk yield was not affected by prepartum treatment in the present study, in agreement with results from a study using a similar experimental design (Holcomb et al., 2001). Component concentrations and yields were not significantly different across treatments, with the exception of milk fat yield and concentration, as previously mentioned.

\section{Hormone and Metabolite Concentrations}

In the present study, glucose concentrations were greater when $\mathrm{NE}_{\mathrm{I}}$ and $\mathrm{EB}$ were greater in the peripartum period, although the differences in the prepartum period were relatively small. When ME intake was similar in the prepartum period across 3 diets of varying forage density and quantity, glucose concentrations were not different across treatments (Moorby et al., 2000). On the other hand, Roche et al. (2005) reported decreased glucose concentrations prepartum with decreasing DMI in dry cows, with the greatest reductions at the lowest intakes when cows were not fed to meet estimated energy requirements.

Plasma concentrations of insulin after parturition were not affected by prepartum treatments in the present study, as has been reported previously (Moorby et al., 2000; Holcomb et al., 2001; Holtenius et al., 2003; Andersen et al., 2004; Accorsi et al., 2005). In the present study, insulin concentrations observed during the prepartum period gradually decreased as parturition approached, and reached the minimum concentrations during the early postpartum period 
(Figure 6). Regardless of intake and energy balance during the prepartum period, Roche et al. (2005) observed no differences in insulin concentration after parturition. Although Holtenius et al. (2003) reported increased prepartum insulin concentrations in cows with greater tissue EB, no differences in postpartum insulin concentration were observed, regardless of prepartum feed intake. In contrast to the present study, a low forage-to-concentrate ratio in prepartum diets fed at ad libitum or limited intake was associated with greater plasma insulin concentrations postpartum, regardless of prepartum intake level (Holcomb et al., 2001).

In other experiments with limited feed allowance prepartum, NEFA concentrations were greater in cows fed diets at intakes that were insufficient to meet energy requirements during the prepartum period (Roche et al., 2005). During the present experiment, although DMI was limited, the amount offered was calculated to be sufficient to meet energy requirements of the pregnant cow (NRC, 2001). The lack of difference in NEFA concentrations between treatments for most of the prepartum period suggests that the $\mathrm{NE}_{\mathrm{I}}$ of the L cows met energy requirements throughout the dry period, as NEFA are mobilized from body tissue when the cow is in negative EB (Pullen et al., 1989). Differences in prepartum energy and feed intake have altered postpartum NEFA concentrations of dairy cows in some studies (Holcomb et al., 2001; Holtenius et al., 2003), but not in others (Roche et al., 2005). In the present study, an increase in plasma NEFA concentration occurred before calving in L cows (Figure 5). The increase on $d-2$ for $L$ cows was associated with an increase in plasma growth hormone concentration, and a decrease in insulin concentration, which did not occur at this time in AL cows (Winkelman et al., 2008). Therefore, the earlier increase in NEFA concentration observed on $\mathrm{d}-2$ in $\mathrm{L}$ cows could be attributed to lipolytic effects of increased growth hormone and decreased insulin concentrations (Bell, 1995).

Plasma concentrations of TNF- $\alpha$ in the present study were within the range of concentrations measured previously in growing cattle (e.g., Elsasser et al., 1997). For both dietary treatments, plasma TNF$\alpha$ concentrations decreased as parturition approached in this study and tended to be lower after calving compared with measurements during the dry period. This was unexpected based on previous observations that mRNA for TNF- $\alpha$ increased on $d 1$ after calving in dairy cows (Loor et al., 2005), and the potential impact of calving stress on TNF- $\alpha$ production. Regardless, the effects of TNF- $\alpha$ at a local (autocrine or paracrine) level may be important as well, and circulating concen- trations may not reflect tissue concentrations and activity unless the immune challenge is severe.

In the present study, although differences in plasma TNF- $\alpha$ concentration between treatments on specific days were significant, they were relatively small and not consistent. Reasons for the numerical decrease in plasma TNF- $\alpha$ concentration at calving in the present study are not certain, but it has been shown previously that exogenous growth hormone or testosterone treatment alters the response of plasma TNF- $\alpha$ concentrations to an endotoxin challenge in calves (Elsasser et al., 1994; Kahl and Elsasser, 2006). Therefore, the reduction in circulating TNF- $\alpha$ measured in dairy cows as they approached parturition may be a consequence of increases in plasma concentrations of growth hormone and estradiol (Winkelman et al., 2008), or other endocrine changes associated with parturition (Bell, 1995). However, the extent to which the changes in plasma concentration we observed reflect changes in tissue (e.g., liver or adipose) production and action of TNF- $\alpha$ are not certain. More research is needed to explore the relationship between plasma and tissue concentrations and the physiological relevance of TNF- $\alpha$ for the metabolism of transition in dairy cows.

\section{CONCLUSIONS}

Cows that were limit-fed during the dry period in the present study did not undergo the characteristic decline in intake, and thus EB, as parturition approached. Limit-fed cows had a more positive EB in the first week after calving, but a more negative EB in wk 2 and 3 of lactation; thus, there was no apparent benefit of limit-feeding in terms of milk production or DMI in the present study. Limit-fed cows also had lower plasma concentrations of glucose over the course of the study, and a lower plasma insulin concentration $2 \mathrm{~d}$ before calving. In addition, limit-fed cows had greater plasma concentrations of NEFA during the last 3 wk before calving, and a marked increase in plasma NEFA concentration $2 \mathrm{~d}$ before calving that was not observed in cows fed ad libitum. In contrast to our hypothesis, limit-feeding did not have positive effects on plasma concentrations of these metabolic indicators after calving, and negative effects were observed in the period immediately before calving. Also in contrast to our expectations, plasma TNF- $\alpha$ concentrations were not increased at calving. The physiological relevance of circulating TNF- $\alpha$ concentrations are not certain and more research is needed to determine the extent to which transition alters TNF- $\alpha$ production and action changes at the tissue level, particularly in the liver. 


\section{ACKNOWLEDGMENTS}

The authors extend appreciation to K. Miller and staff of the Krauss Dairy Farm for provision and care of the cows and to J. Hanson for veterinary care. Also, the authors thank V. Cannon, A. Relling, and D. Wyatt for their technical assistance during the trial. Salaries and research support were provided by state and federal funds appropriated to the Ohio Agricultural Research and Development Center, The Ohio State University (manuscript no. 16/07AS).

\section{REFERENCES}

Accorsi, P. A., N. Govoni, R. Gaiani, C. Pezzi, E. Seren, and C. Tamanini. 2005. Leptin, GH, PRL, insulin, and metabolic parameters throughout the dry period and lactation in dairy cows. Reprod. Domest. Anim. 4:217-223.

Agenäs, S., E. Burstedt, and K. Holtenius. 2003. Effects of feeding intensity during the dry period. 1. Feed intake, body weight, and milk production. J. Dairy Sci. 86:870-882.

Andersen, J. B., N. C. Friggens, T. Larsen, M. Vestergaard, and K. L. Ingvartsen. 2004. Effect of energy density in the diet and milking frequency on plasma metabolites and hormones in early lactation dairy cows. J. Vet. Med. A 51:52-57.

Bell, A. W. 1995. Regulation of organic nutrient metabolism during transition from late pregnancy to early lactation. J. Anim. Sci. 73:2804-2819.

Benson, J. A., and C. K. Reynolds. 2001. Effects of abomasal fat infusion on splanchnic metabolism of pancreatic and gut hormones in dairy cows. J. Dairy Sci. 84:1488-1500.

Bernabucci, U., B. Ronchi, N. Lacetera, and A. Nardone. 2005. Influence of body condition score on relationships between metabolic status and oxidative stress in periparturient dairy cows. J. Dairy Sci. 88:2017-2026.

Bertics, S. J., R. R. Grummer, C. Cadorniga-Valino, and E. E. Stoddard. 1992. Effect of prepartum dry matter intake on liver triglyceride concentration and early lactation. J. Dairy Sci. 75:1914-1922.

Contreras, L. L., C. M. Ryan, and T. R. Overton. 2004. Effects of dry cow grouping strategy and prepartum body condition score on performance and health of transition dairy cows. J. Dairy Sci. 87:517-523.

Doepel, L., H. Lapierre, and J. J. Kennelly. 2002. Peripartum performance and metabolism of dairy cows in response to prepartum energy and protein intake. J. Dairy Sci. 85:2315-2334.

Drackley, J. K. 1999. Biology of dairy cows during the transition period: The final frontier? J. Dairy Sci. 82:2259-2273.

Elsasser, T., K. L. Ingvarsten, S. Kahl, and A. V. Capuco. 2006. Endocrine effects on immune function: Defining opportunities based on knowledge from growing calf and periparturient animal models. Pages 421-453 in Ruminant Physiology. Digestion, Metabolism and Impact of Nutrition on Gene Expression, Immunology and Stress. K. Sejrsen, T. Hvelplund, and M. O. Nielsen, ed. Wageningen Academic Publishers, Wageningen, the Netherlands.

Elsasser, T. H., R. Fayer, T. S. Rumsey, and G. F. Hartnell. 1994. Recombinant bovine somatotropin blunts plasma tumor necrosis factor-alpha, cortisol, and thromboxane-B2 responses to endotoxin in vivo. Endocrinology 134:1082-1088.

Elsasser, T. H., S. Kahl, N. C. Steele, and T. S. Rumsey. 1997. Nutritional modulation of somatotropic axis-cytokine relationships in cattle: A brief review. Comp. Biochem. Physiol. 116:209-221.

Goff, J. P., and R. L. Horst. 1997. Physiological changes at parturition and their relationship to metabolic disorders. J. Dairy Sci. 80:1260-1268.
Grummer, R. R. 1995. Impact of changes in organic nutrient metabolism on feeding the transition dairy cow. J. Anim. Sci. 73:2820-2833.

Hayirli, A., R. R. Grummer, E. V. Nordheim, and P. M. Crump. 2002. Animal and dietary factors affecting feed intake during the prefresh transition period in Holsteins. J. Dairy Sci. 85:3430-3443.

Holcomb, C. S., H. H. Van Horn, H. H. Head, M. B. Hall, and C. J. Wilcox. 2001. Effects of prepartum dry matter intake and forage percentage on postpartum performance of lactating dairy cows. J. Dairy Sci. 84:2051-2058.

Holtenius, K., S. Agenäs, D. Delavaud, and Y. Chilliard. 2003. Effects of feeding intensity during the dry period. 2. Metabolic and hormonal responses. J. Dairy Sci. 86:883-891.

Ingvartsen, K. L., and J. B. Andersen. 2000. Integration of metabolism and intake regulation: A review focusing on periparturient animals. J. Dairy Sci. 83:1573-1597.

Johnson, M. M., and J. P. Peters. 1993. Technical note: An improved method to quantify nonesterified fatty acids in bovine plasma. J. Anim. Sci. 71:753-756.

Kahl, S., and T. H. Elsasser. 2006. Exogenous testosterone modulates tumor necrosis factor-alpha and acute phase protein responses to repeated endotoxin challenge in steers. Domest. Anim. Endocrinol. 31:301-311.

Keady, T. W. J., C. S. Mayne, D. A. Fitzpatrick, and M. S. McCoy. 2001. Effect of concentrate feed level in late gestation on subsequent milk yield, milk composition, and fertility of dairy cows. J. Dairy Sci. 84:1468-1479.

Kenison, D. C., T. H. Elsasser, and R. Fayer. 1990. Radioimmunoassay for bovine tumor necrosis factor: A cytokine mediating metabolic and hormonal perturbations in acute and chronic infection in cattle. J. Immunoassay 11:174.

Kunz, P. L., J. W. Blum, I. C. Hart, H. Bickel, and J. Landis. 1985. Effects of different energy intakes before and after calving on food intake, performance and blood hormones and metabolites in dairy cows. Anim. Prod. 40:219-231.

Loor, J. J., H. M. Dann, R. E. Everts, R. Oliveira, C. A. Green, N. A. Janovick Guretzky, S. L. Rodriguez-Zas, H. A. Lewin, and J. K. Drackley. 2005. Temporal gene expression profiling of liver from periparturient dairy cows reveals complex adaptive mechanisms in hepatic function. Physiol. Genomics 23:217-226.

McNamara, S., F. P. O'Mara, M. Rath, and J. J. Murphy. 2003. Effects of different transition diets on dry matter intakes, milk production, and milk composition in dairy cows. J. Dairy Sci. 86:2397-2408.

Moorby, J. M., R. J. Dewhurst, J. K. S. Tweed, M. S. Dhanoa, and N. F. G. Beck. 2000. Effects of altering the energy and protein supply to dairy cows during the dry period. 2. Metabolic and hormonal responses. J. Dairy Sci. 83:1795-1805.

NRC. 2001. Nutrient Requirements of Dairy Cattle. 7th ed. Natl. Acad. Press, Washington, DC.

Overton, T. R., and M. R. Waldron. 2004. Nutritional management of transition dairy cows: Strategies to optimize metabolic health. J. Dairy Sci. 87(E Suppl.):E105-E119.

Perkins, K. H., M. J. VandeHaar, J. L. Burton, J. S. Liesman, R. J. Erskine, and T. H. Elsasser. 2002. Clinical responses to intramammary endotoxin infusion in dairy cows subjected to feed restriction. J. Dairy Sci. 85:1724-1731.

Pullen, D. L., D. L. Palmquist, and R. S. Emery. 1989. Effect on days of lactation and methionine hydroxy analog on incorporation of plasma fatty acids into plasma triglycerides. J. Dairy Sci. 72:49-58.

Rastani, R. R., R. R. Grummer, S. J. Bertics, A. Gumen, M. C. Wiltbank, D. G. Mashek, and M. C. Schwab. 2005. Reducing dry period length to simplify feeding transition cows: Milk production, energy balance, and metabolic profiles. J. Dairy Sci. 88:1004-1014.

Relling, A. E., and C. K. Reynolds. 2007. Feeding rumen-inert fats differing in degree of saturation decreases intake and increases 
plasma concentrations of gut peptides in lactating dairy cows. J. Dairy Sci. 90:1506-1515.

Roche, J. R., E. S. Kolver, and J. K. Kay. 2005. Influence of precalving feed allowance on periparturient metabolic and hormonal responses and milk production in grazing dairy cows. J. Dairy Sci. 88:677-689.

SAS Institute. 1999. SAS User's Guide: Statistics. Version 8.0. SAS Institute Inc., Cary, NC.

Sordillo, L. M., G. M. Pighetti, and M. R. Davis. 1995. Enhanced production of bovine tumor necrosis-alpha during the periparturient period. Vet. Immunol. Immunopathol. 49:263-270.
Weiss, W. P., and D. J. Wyatt. 2000. Effect of oil content and kernel processing of corn silage on digestibility and milk production by dairy cows. J. Dairy Sci. 83:351-358.

Wildman, E. E., G. M. Jones, P. E. Wagner, R. L. Boman, H. F. Troutt, Jr., and T. N. Lesch. 1982. A dairy cow body condition scoring system and its relationship to selected production characteristics. J. Dairy Sci. 65:495-501.

Winkelman, L. A., M. C. Lucy, T. H. Elsasser, J. L. Pate, and C. K. Reynolds. 2008. Short communication: Suppressor of cytokine signaling-2 mRNA increases after parturition in the liver of dairy cows. J. Dairy Sci. 91:1080-1086. 